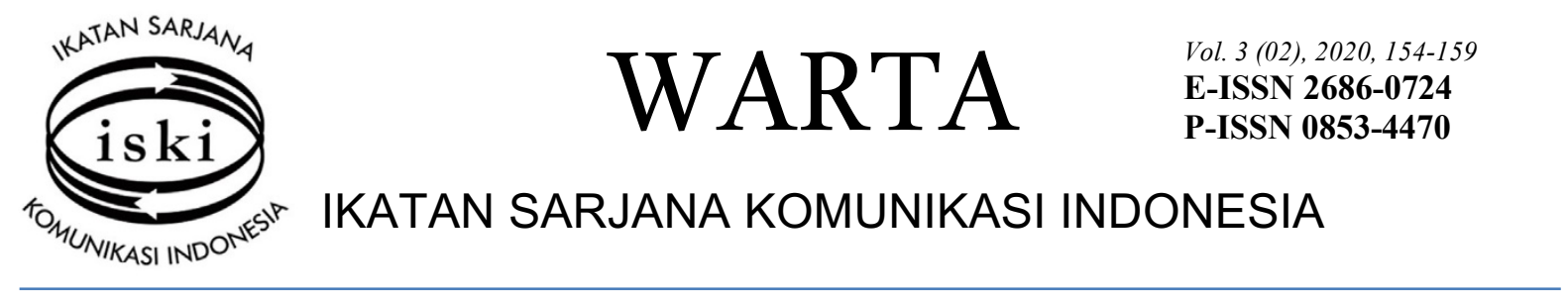

\title{
Motif Penggunaan Aplikasi Musik Spotify pada Generasi-Z di SMA XYZ Bekasi
}

https://doi.org/10.25008/wartaiski.v3i02.64

\author{
Gabriel Putra Josi ${ }^{1 *}$, Weni A. Arindawati², Nurkinan ${ }^{3}$ \\ 1,2,3 Program Studi Ilmu Komunikasi, Universitas Singaperbangsa \\ Jl. HS Ronggo Waluyo, Teluk Jambe Timur, Karawang 41361 - Indonesia \\ *e-mail korespondensi: 1610631190068@student.unsika.ac.id
}

Submitted: 24/09/2020, Revised: 09/12/2020, Accepted: 20/12/2020

Accredited by Kemristekdikti No. 30/E/KPT/2019

\begin{abstract}
This research focuses on SMA XYZ Bekasi students who are z-generation who use the Spotify music application as their main music player application. This study discusses six students of SMA XYZ Bekasi. Through this research, it is expected to be a foundation in understanding the Motives for Using the Spotify Music Application in the Z-Generation. This research uses a descriptive qualitative study. Data collection techniques are carried out through in-depth interviews and unparticipatory observations based on a social action perspective. The results showed that there were four motives behind the students using Spotify. First, social interaction motives, namely motives that arise to meet individual needs in relation to their social environment. Second, entertainment motives, namely things related to getting a sense of pleasure. Third, the information motive is satisfying general curiosity and interest and obtaining a sense of peace through increasing students' knowledge. Fourth, personal identity motives, namely finding support for personal values in the media, finding models in behavior, identifying oneself with other values in the media, and increasing understanding of oneself in using a media.
\end{abstract}

Keywords: Spotify; motive; students; z-generation; music application

\begin{abstract}
Abstrak
Penelitian ini berfokus pada para siswa SMA XYZ Bekasi, merupakan generasi-z yang menggunakan aplikasi musik Spotify sebagai aplikasi pemutar musik. Penelitian ini membahas enam orang siswa SMA XYZ Bekasi untuk memahami motif penggunaan aplikasi musik spotify. Penelitian ini merupakan studi deskriptif kualitatif. Teknik pengumpulan data dilakukan melalui wawancara dan pengamatan nonpartisipatif berdasarkan perpektif tindakan sosial. Hasil penelitian menunjukkan, terdapat empat motif yang melatarbelakangi para siswa menggunakan Spotify. Pertama, motif interaksi sosial yaitu motif yang timbul untuk memenuhi kebutuhan individu dalam hubungan dengan lingkungan sosialnya. Kedua, motif hiburan yaitu hal-hal yang berkenaan untuk mendapatkan rasa senang. Ketiga, motif informasi yaitu memuaskan rasa ingin tahu dan minat umum serta memperoleh rasa damai melalui penambahan pengetahuan para siswa. Keempat, motif identitas pribadi yaitu menemukan penunjang nilai-nilai pribadi dalam media, menemukan model dalam berperilaku, mengidentifikasikan diri dengan nilai-nilai lain dalam media, serta meningkatkan pemahaman tentang diri sendiri dalam menggunakan suatu media.
\end{abstract}

Kata kunci: Spotify; motif; siswa; generasi z; aplikasi musik

\section{PENDAHULUAN}

Perkembangan teknologi kini maju pesat terutama smartphone yang tampil dengan berbagai fitur canggih. Saat ini banyak aplikasi pemutar musik di android dan ios sebagai hasil pengembangan dari smartphone yang tadinya offline kini menjadi online yang terkoneksi ke jaringan internet dan memerlukan paket data untuk mengakses perangkat lunak musik tersebut. Salah satunya adalah Spotify yang berbasis aplikasi pemutar musik dan memberikan informasi tentang musik. 
Spotify merupakan layanan streaming musik dari Swedia yang berdiri 23 April 2006. Dengan Spotify, kita bisa menikmati konten musik ataupun mengunduhnya eksklusif untuk didengarkan pada mode offline. Fitur unduh eksklusif tersedia untuk akun berbayar, mirip dengan konsep Apple Music, radio atau layanan serupa lainnya.

Spotify kini merupakan platform music streaming terdepan. Melihat data di Spotify.com, jumlah pengguna berbayar Spotify telah mencapai 60 juta pada Juli 2017, dengan pengguna aktif 140 juta pencinta musik dari seluruh penjuru dunia. Spotify merupakan pemutar musik streaming yang paling populer di dunia (Gambar 1).

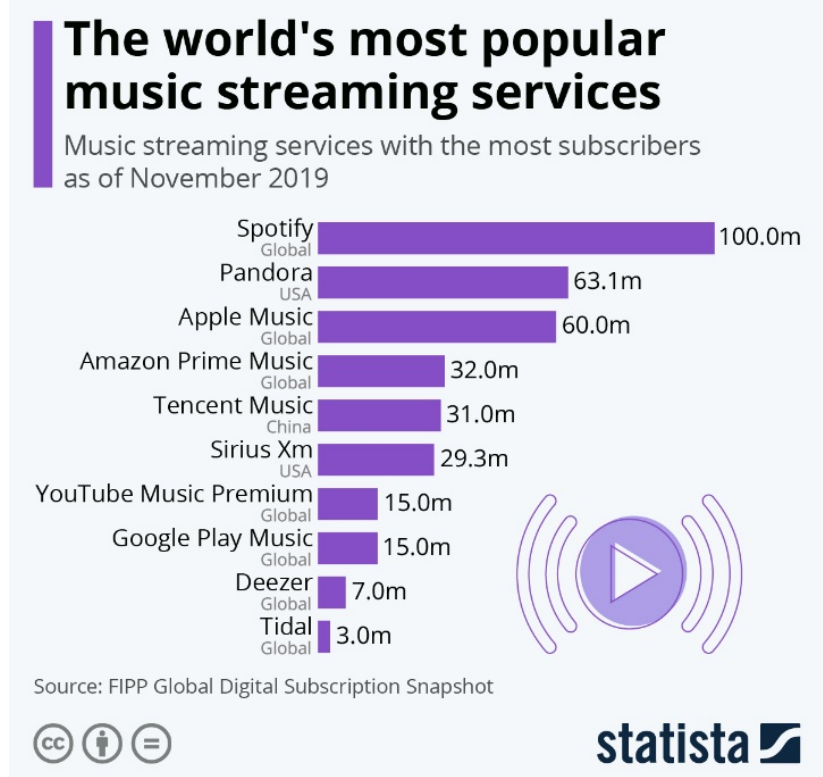

Gambar 1. Urutan pemutar musik streaming di dunia Sumber: www.statista.com

Sebagaian besar pengguna Spotify adalah Generasi $Z$ yang merupakan peralihan dari Generasi $Y$ atau generasi milenial. Pola pikir Generasi $Z$ cenderung serba instan. Generasi ini belum berperan pada bonus demografi Indonesia pada 2020. Generasi-Z merupakan pasar terbesar aplikasi music streaming seperti Spotify. Hingga Maret 2020, pengguna Spotify yang mengunduh aplikasi mobil versi Android sudah mencapai 500 juta orang.

Penelitian yang berkaitan dengan motif penggunaan Spotify tidak banyak dilakukan di Indonesia. Penelitiannya lebih fokus pada bagaimana fenomena Spotify terjadi di Indonesia, seperti yang dilakukan Yollis Michdon Netti, Irwansyah (2018) dan Fahmi Nur Maulana (2017; Tsaniyah, 2019). Penelitian lainnya tentang persepsi brand image Spotify sebagai aplikasi streaming anak muda oleh Audrey Anindia Utami (2018). Penelitian yang dilakukan peneliti di SMA XYZ Bekasi ini adalah untuk menggambarkan bagaimana generasi- $Z$ memenuhi kebutuhan bermedia di bidang music. Dapat dikatakan seseorang menggunakan media karena didorong oleh beraneka ragam motif.

Penelitian ini dilakukan untuk menemukan motif Generasi-Z terhadap penggunaan Spotify sebagai wadah pemutar musik streaming. Fenomena penggunaan aplikasi musik Spotify di lingkungan Generasi-S menjadi fokus penelitian ini. SMA XYZ Bekasi mempunyai banyak siswa yang menggunakan Spotify dalam mengakses musik. Hal yang membuat aplikasi musik Spotify menarik minat mereka karena melalui aplikasi itu mereka dapat mendengarkan musik dari semua genre yang mereka disukai. Inilah yang membuat para siswa penasaran dan ingin menggunakan aplikasi ini. Aplikasi ini juga memberi informasi tentang artis yang mereka sukai.

\section{KERANGKA TEORI}

Teori yang digunakan pada penelitian ini adalah uses and gratification dan teori penggunaan media. Pengguna (uses) isi media mendapatkan pemenuhan (gratification) atas kebutuhan seseorang. Uses and Gratification merupakan pendekatan yang sering digunakan dalam komunikasi. Teori ini 
tidak mewakili keseluruhan proses komunikasi sebab sebagian besar audience hanya dijelaskan melalui berbagai kebutuhan (needs) serta kepentingan (interest) mereka dalam proses penerimaan (pesan media). Uses and Gratification ditujukan untuk penggunaan media si individu atau agregasi individu (Effendy, 2000: 289, Sutrisman, 2019).

Herbert Blumer dan Elihu Katz memperkenalkan teori ini tahun 1974 dalam bukunya The Uses of Mass Communications: Current Perspectives on Gratification Research. Teori ini menyatakan, pengguna media memainkan peran aktif dalam memilih dan memakai media. Pengguna media adalah pihak yang aktif pada proses komunikasi, berusaha mencari media yang paling baik untuk memenuhi kebutuhannya. Teori Uses and Gratifications mengasumsikan, pengguna memiliki alternatif untuk memuaskan kebutuhannya (Nurudin, 2003; Tapsell, 2019).

Menurut McQuail (dalam Rakhmat, 2001:16) pengguna media dipengaruhi oleh motif: (1) motif hiburan sebagai pelarian dari rutinitas sehari-hari; (2) motif integratif sosial, ketika audience menjadikan media sebagai sahabat; (3) motif identitas pribadi, untuk memperkuat nilai-nilai pribadi; (4) motif informasi, bagaimana media membantu seseorang untuk mendapatkan informasi. Hasil mengkonsumsi media berdasarkan motif tertentu itu akan menghasilkan pemuasan bagi pengkonsumsi isi media.

Teori ini menekankan pendekatan manusiawi dalam melihat media massa, artinya manusia mempunyai otonomi dan wewenang memperlakukan media. Dalam studi ini, media dimaksud adalah Spotify yang diakses siswa untuk mendapatkan informasi musik melalui fitur-fitur yang ditawarkan, serta sebagai ajang dalam melakukan interaksi sosial sebagai identitas diri.

\section{METODE PENELITIAN}

Studi ini merupakan penelitian fenomenologi, menggunakan pendekatan kualitatif yang bersifat naratif. Teknik pengumpulan data dilakukan melalui observasi, wawancara serta analisis dokumen. Pendekatan kualitatif menurut Corbin serta Strauss (2015) merupakan bentuk penelitian di mana peneliti dalam mengumpulkan dan menganalisis data sebagai bagian dari proses penelitian: menjadi partisipan bersama informan yang memberikan data (Yusuf, 2016).

Adapun alasan menggunakan pendekatan kualitatif adalah: (1) untuk mengeksplorasi pengalaman batin peserta; (2) mengeksplorasi bagaimana makna terbentuk dan ditransformasikan; (3) menjelajahi wilayah yang belum diteliti secara menyeluruh; dan (4) untuk mengambil pendekatan dan komprehensif realitas lapangan.

Informan penelitian dipilih berdasarkan kriteria yang dapat dijadikan acuan yaitu: (1) harus mengalami langsung situasi atau kejadian yang berkaitan dengan topik penelitian; (2) mampu menggambarkan fenomena yang dialaminya, terutama dalam sifat alamiah dan makna; (3) bersedia diwawancarai selama penelitian berlangsung; (4) memberikan persetujuan untuk mempublikasikan hasil penelitian.

Berdasarkan kriteria tersebut, maka informan penelitian ini adalah: (1) laki-laki/perempuan; (2) usia 15-18 tahun; (3) menggunakan Spotify kurang lebih selama enam; dan (4) terdaftar sebagai siswa aktif di SMA XYZ Bekasi.

Metode pengumpulan data yang dipergunakan adalah metode observasi dan wawancara. Observasi dibagi menjadi dua, yaitu observasi partisipan dan observasi nonpartisipan (Berliana, 2018). Pada penelitian ini peneliti menggunakan observasi nonpartisipan, peneliti tidak terlibat pada kegiatan sehari-hari objek yang diteliti, namun hanya menjadi pengamat. Wawancara juga dibagi sebagai dua, yaitu wawancara terstruktur serta wawancara tidak terstruktur. Dalam penelitian ini, peneliti menggunakan wawancara terstruktur untuk mendapatkan data penelitian.

Teknik lain yang digunakan pada pengumpulan data adalah menelaah dokumen yang ada untuk mempelajari pengetahuan atau fakta yang diteliti untuk memperkuat informasi tentang motif penggunaan aplikasi pemutar musik Spotify pada Generasi-Z.

\section{HASIL PENELITIAN}

Aplikasi Spotify merupakan karya Daniel Ek dan Martin Lorentzon tahun 2005. Keduanya mengemukakan gagasan tentang layanan Spotify, sambil berbagi musik di sebuah apartemen di Swedia. Mereka meluncurkan versi beta tahun 2007 (Crook \& Tepper, 2015). Aplikasi resminya diluncurkan pertama kali pada 7 Oktober 2008. Spotify terus berkembang, dan sejak itu berekspansi di lebih dari 56 negara. Dalam perkembangannya, Spotify bekerjasama dengan Universal Music Group, Warner Music, 
EMI Group, Sony Music Entertainment, dan Merlin untuk mencapai pasar yang luas (Kiendl, 2014, Ward, 2015).

Sebagai sebuah platform musik streaming, aplikasi Spotify dapat dijalankan pada berbagai perangkat digital seperti ponsel pintar, desktop, tablet, playstation, xbox, smart TV, hingga perangkat audio berbasis bluetooth. Untuk menjalankan aplikasi Spotify, user harus mengunduh aplikasi Spotify terlebih dahulu di perangkat yang dimilikinya. Selanjutnya pengguna memilih layanan berbayar (premium) atau layanan gratis. Dengan membayar Rp. 49.900 perbulan, pengguna dapat mendengarkan musik secara offline, tanpa iklan dan mendapat kualitas audio lebih bagus daripada layanan versi gratis (Spotify.com, 2017).

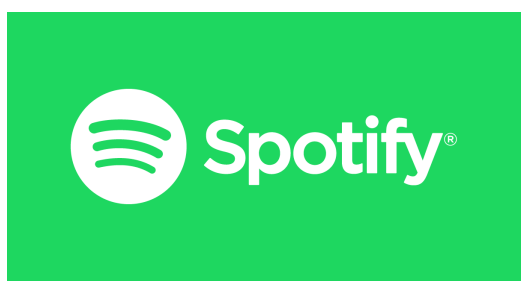

Gambar 2. Logo Spotify

Sumber : www.spotify.com

Spotify beroperasi dengan dukungan iklan dan layanan berbayar. Dalam menjalankan bisnisnya, komponen biaya terbesar adalah biaya penjualan, termasuk pembayaran lisensi musik. Ada tiga model berlangganan Spotify, yaitu: (1) Spotify Gratis. Pengguna mengunduh dan mendengarkan Spotify secara gratis. Sebagai kompensasinya, terdapat layanan iklan berupa audio dan display di sana; (2) Spotify Premium, membayar biaya berlangganan Rp. 49,900 perbulan (umum), Rp. 24,900,- (pelajar), dan Rp. 79,000 untuk keluarga dengan lima account (Spotify.com, 2017).

Setelah melalukan serangkaian pengamatan dan wawancara terhadap informan, ditemui data atas motif yang ada di kalangan siswa SMA XYZ Bekasi dalam menggunakan aplikasi pemutar musik Spotify. Selengkapnya terangkum dalam Tabel 1:

Tabel 1. Motif siswa SMA XYZ Bekasi menggunakan aplikasi Spotify

\begin{tabular}{|c|c|}
\hline $\begin{array}{c}\text { Motif } \\
\text { Interaksi } \\
\text { Sosial }\end{array}$ & $\begin{array}{l}\text { - Motif Interaksi Sosial adalah Motif yang timbul untuk memenuhi kebutuhan individu } \\
\text { dalam hubungan dengan lingkungan sosialnya. } \\
\text { - Siswa menggunakan aplikasi pemutar musik Spotify sebagai media untuk berinteraksi } \\
\text { dengan teman dengan menggunakan perantara dari aplikasi pihak ketiga. Spotify bekerja } \\
\text { sama dengan facebook, Instagram, whatsapp dan aplikasi media sosial lainnya untuk } \\
\text { memudahkan para penggunanya dalam membagikan lagu serta informasi yang terdapat } \\
\text { di dalamnya dengan lewat satu pilihan yaitu tombol "Share". } \\
\text { - Siswa SMA XYZ Bekasi memanfaatkan Spotify untuk memberitahu lagu yang mereka } \\
\text { suka atau yang sedang mereka dengarkan kepada teman-temannya. }\end{array}$ \\
\hline $\begin{array}{c}\text { Motif } \\
\text { Hiburan }\end{array}$ & $\begin{array}{l}\text { - Motif Hiburan adalah hal-hal yang berkenaan untuk mendapatkan rasa senang. } \\
\text { - Motif hiburan Aplikasi Pemutar Musik Spotify tak hanya sebagai wahana interaksi } \\
\text { sosial, namun juga dapat menjadi media untuk mendapatkan keuntungan dari fasilitas } \\
\text { yang diberikan oleh Spotify. Salah satu contohnya adalah mereka dapat mendengarkan } \\
\text { lagu dengan genre yang mereka sukai di manapun dan kapanpun dengan kualitas suara } \\
\text { yang jernih. }\end{array}$ \\
\hline $\begin{array}{c}\text { Motif } \\
\text { Informasi }\end{array}$ & $\begin{array}{l}\text { - Motif informasi yaitu memuaskan rasa ingin tahu dan minat umum serta memperoleh rasa } \\
\text { damai melalui penambahan pengetahuan. Siswa SMA XYZ Bekasi tidak hanya } \\
\text { menggunakan Spotify sebagai ajang hiburan, melainkan memakai Spotify untuk } \\
\text { mendapatkan informasi update tentang tangga lagu saat ini atau mengenai artis-artis } \\
\text { favorit mereka. Sebagai generasi yang paling banyak menggunakan smartphone setiap } \\
\text { harinya, mereka merasa Spotify memberikan kemudahan dalam menemukan kebutuhan } \\
\text { mereka salah satunya adalah kebutuhan informasi. Setiap orang membutuhkan informasi } \\
\text { untuk memenuhi rasa penasaran mengenai sesuatu, menunjang kebutuhannya, atau } \\
\text { sekedar memberikan inspirasi dan menambah pengetahuan. Sebagai seseorang yang } \\
\text { selalu menggunakan Spotify, mereka juga mencari dan berusaha memenuhi kebutuhan }\end{array}$ \\
\hline
\end{tabular}




\begin{tabular}{|c|l|}
\hline & $\begin{array}{l}\text { mereka terhadap informasi melalui aplikasi ini yang memberikan kemudahan untuk } \\
\text { mengakses atau menemukan informasi melalui fitur-fitur da nisi konten yang terdapat } \\
\text { didalamnya. Berbagai informasi dengan mudah ditemukan, khususnya informasi- } \\
\text { informasi mengenai tangga lagu atau musik apa yang sedang trending saat ini, semuanya } \\
\text { terangkum dalam fitur tangga lagu pada Spotify. }\end{array}$ \\
\hline $\begin{array}{c}\text { Motif } \\
\text { Identitas Diri }\end{array}$ & $\begin{array}{l}\text { Motif identitas pribadi adalah menemukan penunjang nilai-nilai pribadi dalam media, } \\
\text { menemukan model dalam berperilaku, mengidentifikasikan diri dengan nilai-nilai lain } \\
\text { dalam media, serta meningkatkan pemahaman tentang diri sendiri dalam menggunakan } \\
\text { suatu media. }\end{array}$ \\
\hline
\end{tabular}

Saat perkembangan teknologi internet dan telepon seluler makin maju maka aplikasi serta fiturfitur dalam ponsel pun ikut tumbuh dengan pesat. Kini dengan menggunakan Spotify kita bisa mendengarkan musik digital di mana saja dan kapan saja dengan menggunakan ponsel pintar. Begitu cepatnya orang mengakses internet, mengakibatkan terjadinya fenomena besar terhadap arus informasi, tidak hanya di negara-negara maju, tetapi juga di Indonesia.

Spotify sebagai aplikasi pemutar musik online memanfaatkan kondisi itu, sehingga dimana setiap orang bisa mendengarkan musik favorit mereka lewat ponsel mereka, dengan terhubung ke internet untuk mendapatkan pustaka lagu yang lengkap dari seluruh penjuru dunia.

Media baru telah memunculkan teknologi digital, computer, atau jaringan teknologi informasi komunikasi di akhir abad ke-20. Karakteristik new media adalah dapat diubah, bersifat jaringan, padat, interaktif dan bersifat user generated content, yakni konten artikel di internet yang ditulis oleh khalayak umum dapat diakses oleh semua orang.

Motif informasi merupakan suatu kebutuhan sehingga lewat Spotify, para siswa berupaya untuk mendapatkan informasi mengenai artis serta lagu-lagu favorit mereka. Pengguna Spotify selain untuk mendengarkan musik, juga untuk mengetahui maksud lagu itu ditulis lewat fitur "Behind The Lyrics". Pemenuhan informasi yang selalu up-to-date menjadi kebutuhan yang tidak dapat dibiarkan. Para siswa ingin mengetahui informasi yang terjadi di tingkat nasional maupun internasional terutama yang berkaitan dengan musik.

Salah satu karakteristik new media adalah user generated content, tidak hanya orang yang berkepentingan yang dapat mengakses kontennya namun dapat diakses juga oleh semua orang. Seperti Spotify, lagu dan musiknya dapat diakses dan didengar dengan bebas. Lewat aplikasi Spotify para siswa membagikan lagu yang mereka dengar kepada orang lain melalui aplikasi pihak ketiga seperti Instagram, Whatsapp, dan Facebook.

Lagu atau musik yang mereka bagikan sering kali mewakili perasaan serta mood mereka pada saat itu. Ketika mereka sedang galau, mereka cenderung membagikan lagu melow sedangkan ketika mood sedang baik, mereka membagikan lagu gembira. Namun di antara mereka terdapat pula yang beranggapan, musik hanya untuk dirinya sendiri. Informan M, memutar musik hanya untuk menghibur diri sendiri dan tidak membagikan lagu yang sedang ia dengarkan kepada siapapun.

Motif interaksi sosial berkaitan dengan kebutuhan terhadap komunikasi dengan keluarga, teman dan dunia sekitar serta memperoleh pengetahuan dan informasi tentang keadaan orang lain serta menumbuhkan rasa simpati dan empati. Hal ini sesuai dengan salah satu ciri new media, yaitu komunikasi timbal balik (interaktivitas). Penerima dapat memilih, menukar informasi, menjawab kembali, dan dihubungkan dengan penerima lainnya secara langsung.

Para Siswa SMA XYZ Bekasi dalam memenuhi kebutuhan hiburan, mereka mengakses Spotify. Informasi dan konten dalam berbagai jenis genre musik yang tersedia di Spotify membuat mereka tidak pernah bosan dan jenuh karena konten Spotify selalu update, mulai dari lagu-lagu yang baru serta tangga lagu selalu diperbaharui setiap minggunya.

Spotify memiliki kelenturan bentuk, isi, dan penggunaannya, dan pengguna Spotify bebas menggunakan konten sesuai dengan keinginan pengguna dalam memenuhi motif hiburan. Para siswa SMA XYZ Bekasi dapat mengidentifikasi diri dengan nilai-nilai yang terkandung dalam aplikasi Spotify dan memberikan dampak kepada mereka: membagikan lagu yang mereka dengar kepada temantemannya. Kondisi itu merupakan bentuk mengekspresikan diri.

Kegiatan pemenuhan kebutuhan pada identitas pribadi melalui Spotify tersebut, selaras dengan teori new media, yaitu interaksi sosial merupakan gambaran media, bukan hanya dalam bentuk 
informasi atau penyebarannya, tetapi juga dalam bentuk ritual. Singkatnya, bagaimana manusia menggunakan media sebagai cara menciptakan masyarakat. Media bukan hanya sebuah instrument informasi atau cara untuk mendapatkan identitas diri, tetapi juga untuk menyatukan manusia dalam masyarakat.

\section{KESIMPULAN}

Kesimpulan penelitian ini adalah, terdapat empat motif di kalangan pelajar SMA XYZ Bekasi untuk menggunakan aplikasi Spotify yakni:

(1) Motif interaksi sosial. Siswa menggunakan aplikasi pemutar musik Spotify untuk membagikan lagu-lagu yang sedang mereka dengarkan kepada teman, keluarga dan kerabat-kerabatnya dengan menggunakan aplikasi pihak ketiga;

(2) Motif untuk menemukan informasi. Siswa SMA XYZ Bekasi menggunakan Spotify untuk memenuhi kebutuhan mereka atas informasi mengenai artis dan lagu favorit mereka, karena Spotify selalu mengupdate lagu-lagu terbaru.

(3) Motif Hiburan. Siswa SMA XYZ Bekasi menggunakan Spotify untuk memenuhi kebutuhan terhadap hiburan melalui fitur-fitur yang diberikan oleh pihak Spotify. Selain memberikan informasi mengenai artis dan lagu-lagu favorit para siswa, Spotify juga menyediakan pustaka lagu yang lengkap dan beragam. Selain itu Spotify dapat diakses dan digunakan di mana dan kapan saja.

(4) Motif Identitas Pribadi. Para siswa SMA XYZ Bekasi beranggapan pada saat mereka menggunakan Spotify ada dorongan positif yang keluar dari dalam diri mereka sehingga mereka merasa lebih percaya diri. Ada juga yang beranggapan Spotify merupakan ketika menggunakan Spotify perasaan mereka menjadi lebih nyaman.

\section{DAFTAR PUSTAKA}

Berliana, N. (2018). Advertising and Promotion, An Integrated Marketing Communications Perspective. Singapore: McGraw-Hill.

Effendy, O.U. (2000). Ilmu Komunikasi Teori dan Praktek, Bandung: Remaja Rosdakarya.

Kiendl, W. (Mei 2014). Spotify's Time. Music Business Journal (Berklee College of Music).

The MBJ.org. Diakses dari: http://www.thembj.org/2014/05/spotifys-time/

Netti, S. Y. M., \& Irwansyah, I. (2018). Spotify: Aplikasi Music Streaming untuk Generasi Milenial. Jurnal Komunikasi, 10(1), 1. https://doi.org/10.24912/jk.v10i1.1102

Nurudin. 2003. Komunikasi Massa. Cespur: Malang.

Sutrisman, D. (2019). Pendidikan Politik, Persepsi, Kepemimpinan, dan Mahasiswa. Jakarta: Guepedia Publisher.

Tapsell, R. (2019). Indonesia's Policing of Hoax News Increasingly Politicised.

Tsaniyah, N., \& Juliana, K. A. (2019). Literasi Digital sebagai Upaya Menangkal Hoax di Era Disrupsi. Al-Balagh: Jurnal Dakwah dan Komunikasi, 4(1), 121.

Ward, M. O., Grinstein, G., \& Keim, D. (2015). Interactive Data Visualization: Foundations, Techniques, and Applications. New York: CRC Press.

Yusuf, M. (2016). Metode Penelitian Kuantitatif, Kualitatif \& Penelitian Gabungan. Jakarta: Prenada Media. 